Article

\title{
An Indicator-Based Approach for Analyzing the Resilience of Transitions for Energy Regions. Part I: Theoretical and Conceptual Considerations
}

\author{
Claudia R. Binder ${ }^{1,2, *}$, Susan Mühlemeier ${ }^{1,2}$ and Romano Wyss ${ }^{1,2}$ \\ 1 Laboratory for Human Environment Relations in Urban Systems (HERUS), Swiss Mobiliar Chair in Urban \\ Ecology and Sustainable Living, Institute of Environmental Engineering, ENAC, École Polytechnique \\ Fédéral de Lausanne (EPFL), CH-1015 Lausanne, Switzerland; susan.muehlemeier@epfl.ch (S.M.); \\ romano.wyss@epfl.ch (R.W.) \\ 2 Research and Teaching Unit in Human-Environment Relations, Department for Geography, \\ Ludwig-Maximilian University Munich (LMU), 80539 München, Germany \\ * Correspondence: claudia.binder@epfl.ch; Tel.: +41-21-693-93-62
}

Academic Editor: Stefan Gößling-Reisemann

Received: 14 November 2016; Accepted: 23 December 2016; Published: 1 January 2017

\begin{abstract}
The transition of our current energy system from a fossil-based system to a system based on renewables is likely to be one of the most complex and long-term societal transitions in history. The need for a fundamental system transformation raises the question of how to measure the continuing progress and the resilience of this process over time. This paper aims at developing the conceptualization and operationalization of resilience for energy systems in transition with regard to both social and technical aspects. Based on the resilience concept in social-ecological systems literature, we propose to conceptualize resilience for energy systems building on two core attributes of resilience, namely diversity and connectivity. We present an indicator set to operationalize these key attributes in social and technical systems using: (i) definitions and measurements for three fundamental diversity properties—variety, balance and disparity—and (ii) basic connectivity properties from the social network analysis literature - path length, centrality and modularity. Finally, we reflect on possibilities for an application of these indicators in the social and technical system's spheres and discuss the added value of the approach for energy transition research.
\end{abstract}

Keywords: resilience; energy transition; socio-technical systems; social-ecological systems; diversity; connectivity

\section{Introduction}

The envisaged transition of the energy system towards greater sustainability is one of the major challenges of the 21st century [1]. A number of countries have set specific transition goals, and have invested heavily in both technology development and infrastructure measures [2-10]. From an analytical perspective, energy transition processes can be understood as a succession of both intended disruptive changes and incremental adaptation processes along a specific change path [11]. Throughout the change process, humans have to anticipate, to adapt to, and to learn from and within fundamentally new situations, while taking into account the technical possibilities at disposition $[12,13]$. According to Grin et al. [14] "[transition processes] are interwoven with economic sectors (mobility, housing, agriculture) and in fact deeply rooted in our societal structures, routines and culture." The transition of the energy system towards renewable energies and higher energy efficiency is a complex, and long-term societal change. This implies that the transition of the energy system has to be analyzed in an integrative way, taking into account the co-evolution of technological and societal factors [15]. 
In the energy transition literature, decentralized energy systems are increasingly seen as being key for achieving a low-carbon, renewable energy system [16]. As such the role of the regional level has increasingly gained importance as has already been acknowledged by the European Union [17]. For the remainder of the paper, we understand regions as territorial entities approximately the size of nomenclature of territorial units for statistics (NUTS)-3 as defined by the European Union [18]. Several scholars have analyzed the relevant factors for an energy transition at regional level. Main points that have been discussed are the role of guiding visions and foresight, the characteristics of the actors and social arenas involved in the transition process, the way institutionalization takes place, and the development of the energy and material flows over time [19-27]. A handful of scholars have developed models for analyzing and simulating transition processes [28-30]. These studies identified, amongst others, the following issues: (i) Guiding visions are essential for initiating the transition [20-22,31-33]; (ii) There is a significant delay between the initial vision until some physical changes can be observed [19,23]; and (iii) the engagement of communal and regional stakeholders is key to establishing a new governance structure through connecting actors in collaborative networks and regional action arenas [34].

What has often not been explicitly integrated in these analyses is the fact that for a transition to be successful, a faultless functioning of the energy system along the transition path is paramount [35]. In other words, the system has to remain resilient to external and internal shocks and unplanned disruptions throughout the transition process $[34,36,37]$. For this to be achieved, both the technical properties of the systems in transition as well as the connection to the social sphere have to be considered along the different phases of the transition pathway (Figure 1). While social actors are important to drive the transition, a faultless functioning of the technical energy production and distribution systems is important both from an economic and political point of view to ensure public support, and prevent unwanted disruptions of the transition process [38].

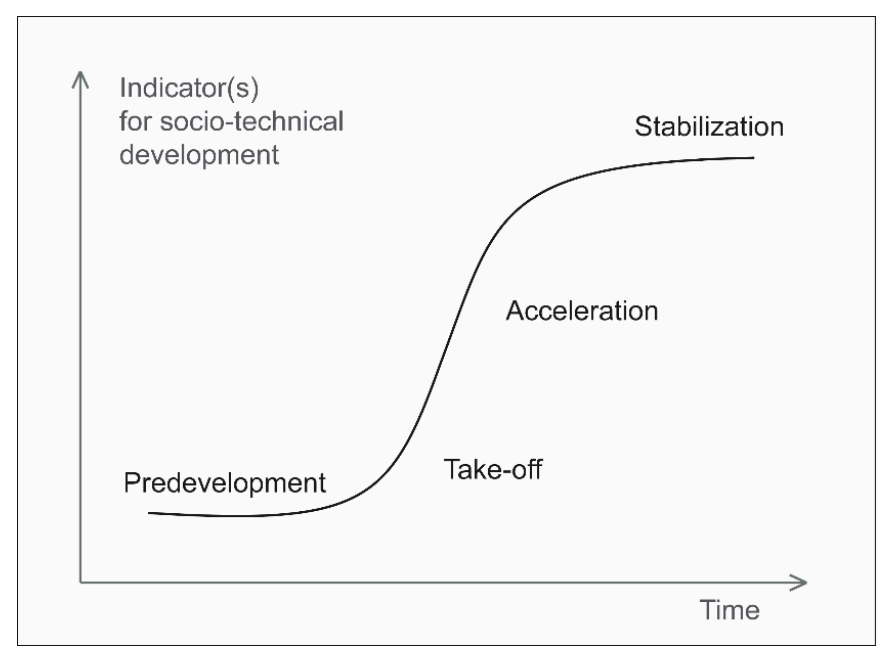

Figure 1. The four transition phases of socio-technical transitions (based on [11]).

When conceptually defining the resilience of the energy transition we have to understand what an energy transition implies and which aspects of the social and technical subsystems change in which way along the transition pathway. Envisioning the co-evolution between the social and the technical subsystems, one should be able to observe emerging institutions and new players, e.g., new businesses such as energy producers or suppliers of raw materials and the related changes in the governance structure it goes in hand with. In addition, potential new funding mechanisms which would support and foster the transition have to be taken into account [19,23,39-43]. When looking at the technical aspects of the system, we expect the energy transition to bring about (i) development and utilization of new technologies; (ii) increasing share of new (renewable) technologies in mix of energy generation; 
and (iii) become flexible as to deal with fluctuation in the loads and supply volatility $[23,28,44-46]$. Whereas the changes to be obtained seem to be clearly defined, there is lack of knowledge regarding the resilience during the transition process itself or there is the need for "building the resilience of a new direction" [47].

To our knowledge, no studies to date have explicitly analyzed and operationalized the factors that affect the resilience of an energy system along a transition pathway, both from a social and a technological perspective. In this paper we address this issue from a theoretical and conceptual point of view. We aim at: (i) Conceptualizing the role of resilience with regard to both social and technical aspects of energy transitions; (ii) Developing a set of indicators to analyze the resilience of the energy system throughout the transition process; and (iii) giving first insights into how these indicators might relate to transition processes.

We organize the paper along the following sections. We start off with a theory-driven conceptualization of how to understand resilience for energy systems in transition in section two. We then propose an operationalization of the resilience of energy systems based on a set of six indicators for both diversity and connectivity in section three. In section four we discuss the possible application of the resilience indicators in energy systems, before we conclude with general insights and further research ideas in section five.

\section{Conceptualizing Resilience of Systems in Transition}

Resilience can be described as "the capacity of a system to absorb disturbance and reorganize while undergoing change so as to still retain essentially the same function, structure, identity, and feedbacks" [48]. In the same line of thought, [49] describes resilience of a system as the capacity of the system and its components to withstand shocks (stability) as well as to adjust to changing external conditions (adaptive capacity), based on the flexibility of the system's configuration. Systems themselves can be understood as an ensemble of qualitatively diverse system components and their interlinkages, e.g., by means of flow of energy, or information. Based on this system understanding, resilience can be defined as a function of the diversity of system components and the connectivity patterns between the components [50,51].

In the tradition of systems thinking in a social-ecological systems (SES) understanding, research following the seminal work by $[52,53]$ in the field of ecology has pointed to both static and dynamic elements of resilience, allowing a system to stay in a dynamic equilibrium state where system elements are in a sustainable relation to one another, not endangering the long-term stability of the system [54,55]. A key concept in SES resilience is the adaptive cycle $[53,55,56]$. The core idea behind the adaptive cycle is that as ecological and social systems are forced to adapt to internal and external change, on different scales and over different spaces of time, the fundamental characteristics of the system changes in terms of both diversity and connectivity.

In comparison to the SES literature, resilience thinking has only sporadically been used as an explanatory concept in socio-technical (STS) studies. Aside from studies with a strong technical orientation $[44,57,58]$, the only scholars who have tried to link a comprehensive resilience concept to socio-technical issues to our knowledge are $[59,60]$. The authors stress the commonalities between SES and STS as complex adaptive systems, and base their call for an application of resilience as a guiding research concept to STS on the argument that, very much as in SES, STS research should be able to give informed policy recommendations in how to support the progress towards more sustainable societies, and therefore must also give answers "over who governs, whose system framings count, and whose sustainability gets prioritized" [60].

For the remainder of the paper, we build on this understanding of resilience in STS by combining the SES resilience concept with a STS systems understanding [55,60-62], which is based on the idea that socio-technical transformation processes go hand in hand with a co-development of the social and technical system $[63,64]$. Within this understanding, ecological aspects are indirectly accounted for via the resource-base that underlies the respective technologies. We consider a transition resilient if the 
resulting system is resilient along the whole transition process, in analogy to the phases of the adaptive cycle [56]. Thus, during a resilient energy transition the systems will pass through stable and adaptive stages, characterized by differing configurations of both the social and the technical components of the energy system, but will never lose its overall resilience.

\section{Operationalizing Resilience of Energy Systems in Transition}

Based on the resilience understanding presented above, we propose to operationalize the resilience of energy systems in transition building on two core attributes of resilience, namely diversity and connectivity [50,51]. While the measure of diversity is linked to the structural attributes of the system, connectivity is process oriented and related to the interaction between the system components [65-67]. Following [56], these two system characteristics co-determine a system's structural stability and adaptive capacity in the face of continuously changing external conditions, as well as in the face of disruptive shocks. According to Holling (1973) "Stability, ... , is the ability of a system to return to an equilibrium state after a temporary disturbance. The more rapidly it returns to an equilibrium state and with the least fluctuation, the more stable it is".

This implies that there is a need for a minimal level of both component-based diversity and interaction-based connectivity so that resilience of the system be attained, while the levels of diversity and connectivity will vary along the transition pathway in order for the system to maintain its adaptive capacity [68].

Operationalization of social sphere: social arenas

With respect to the analysis of the social system, one possibility to tackle the great number of actors and their complex interaction patterns is to work with the concept of "social arenas" [20,32]. Social arenas are defined as "societal subsystems or spheres, characterized by their rationality and codes depending on their function" (translated from [20]). Commonly these arenas are differentiated through their specific structure and their functional characteristics, distinguishing, e.g., between the political, the entrepreneurial or the private household arena. For the transition to be resilient and to ensure the functionality of the system, actors of different arenas have to be included and they have to collaborate with each other [37]. Thereby, we look at social connectivity as the exchange patterns between actors from different social arenas, while we consider diversity as the functional qualitative difference between arenas.

Operationalization of the technical sphere: technologies

With respect to the technical system, we distinguish between different groups of (renewable) energy production technologies. Kost et al. [69] have applied a differentiation in production technology groups with respect to their (relative) locality. This is more precise than only studying the energy sources and it is less detailed than analyzing each specific technology. For the determination of diversity, we suggest to consider different forms of technologies, such as hydropower (small and big plants), photovoltaic (rooftop and open field), solar thermal energy, biomass heating, and combined heat power production (CHP). With regard to connectivity, we base our operationalization on the transmission infrastructure that links the various production entities amongst each other, and to the consumers. In the following subsections, we suggest six metrics for measuring diversity and connectivity, accounting for both the social and the technical components of the energy system.

\subsection{Diversity}

According to [70] the definitions and measurements of diversity are similar across disciplines and system contexts. Diversity can be conceptualized by three fundamental properties: Variety, balance and disparity (Table 1). Each of these properties has been found to be necessary but insufficient to conceptualize diversity [71,72]. Scholars have still, not found a fourth property which is relevant for diversity [70]. 
Table 1. Suggested measures for operationalizing diversity in socio-technical energy systems (based on [70]).

\begin{tabular}{|c|c|c|c|}
\hline $\begin{array}{l}\text { Diversity } \\
\text { Indicator }\end{array}$ & Definition & Social System & Technical System \\
\hline Variety & Category count $\mathrm{N}$ & $\begin{array}{l}\text { Number of types of social arenas } \\
\text { present in the regional energy } \\
\text { governance structure } \\
\text { Role for resilience: } \\
\text { Higher adaptability and stability } \\
\text { through integration of different } \\
\text { views and perspectives }\end{array}$ & $\begin{array}{l}\text { Number of groups of } \\
\text { technologies present in the local } \\
\text { energy production system } \\
\text { Role for resilience: } \\
\text { Integration of different } \\
\text { technologies, basis for flexibility } \\
\text { and adaptability }\end{array}$ \\
\hline Balance & $\begin{array}{l}\text { Shannon evenness } \\
S=-\sum_{i} \frac{p_{i} \ln \left(p_{i}\right)}{\ln N} \\
\text { Shannon Weaver } \\
\text { (includes variety) } \\
S=-\sum_{i} p_{i} \ln \left(p_{i}\right)\end{array}$ & $\begin{array}{l}\text { Number of actors per social arena } \\
\text { in comparison to overall number } \\
\text { of actors } \\
\text { Role for resilience: } \\
\text { Indicator for stability, efficiency, } \\
\text { flexibility }\end{array}$ & $\begin{array}{l}\text { Share of technology groups in } \\
\text { overall energy production } \\
\text { Role for resilience: } \\
\text { Shows how much the region } \\
\text { relies on one energy technology } \\
\text { group (energy portfolio) }\end{array}$ \\
\hline Disparity & $\begin{array}{c}D_{i}=f\left(d_{i j}\right) \\
f\left(d_{i j}\right) \text { : function of distance } \\
\text { in disparity space between } \\
\text { categories } i \text { and } j\end{array}$ & $\begin{array}{l}\text { Qualitative differentiation } \\
\text { between arenas } \\
\text { Role for resilience: } \\
\text { Determines stability, transaction } \\
\text { costs and flexibility }\end{array}$ & $\begin{array}{l}\text { Qualitative differentiation } \\
\text { between technologies } \\
\text { Role for resilience: } \\
\text { Diverse technologies-basis for } \\
\text { adaptability to uncertain } \\
\text { external shocks }\end{array}$ \\
\hline
\end{tabular}

\subsubsection{Variety}

Variety is "the number of categories (we use the term type) into which system elements are apportioned" [70]. According to [70], "all else being equal, the higher the variety, the greater the diversity". It is quantified by the "category count" (N; Table 1$)$.

Social: In the social system, variety relates to the question of how many types of social arenas are prevalent in the governance structure of the regional energy system (e.g., politics, industry, research, society or media). Role for resilience: From a resilience perspective increasing variety of social arenas leads to an increasing amount of perspectives and viewpoints present in the regional energy discourse. This can lead to an increasing adaptive capacity but potentially less stability, which might be supportive for systemic change. A low variety of social arenas can imply less diverse perspectives and viewpoints but potentially higher stability. A too low variety on a long run, however, might also lead to the destabilization of the systems, as relevant actor groups (arenas) might be excluded.

Technical: In the technical system, variety refers to the amount of different types of renewable energy technologies present in the region (e.g., photovoltaic, solar heat, hydropower, combined heat and power, [60]). Role for resilience: A large variety of technologies might destabilize and increase the costs of the energy system, as, e.g., technologies within different load types (base load and peak load) have to be aligned and integrated into the system $[45,46,73,74]$. This lowers the actual stability but can increase the adaptive capacity: a high variety of technology groups also represents a window of opportunity where new technologies emerge and potentially lead to a system change if they can be integrated into the existing structure. At the stabilization point of the transition, the best suited technologies establish themselves. A low variety within the technical system contributes to stability but lowers the potential adaptive capacity of the energy system, which might be needed to react to external shocks.

\subsubsection{Balance}

Balance relates to the patterns of allocation of the elements across the different categories. Stirling [70] proposes several indicators for measuring the balance. The most popular and easiest to use is the Shannon index. The Shannon evenness index [60] is the one explicitly used to measure the balance (Table 1, Equation (1)): 
Shannon Evenness-Pielou

$$
S=-\sum_{i} \frac{p_{i} \ln \left(p_{i}\right)}{\ln N}
$$

where $\ln$ the natural logarithm and $p_{i}$ the proportion of system category $i[60] ; N$ : number of types of arenas or energy technology groups.

Kharrazi et al. [75] suggested applying the Shannon-Weaver index which combines the variety and balance (Table 1, Equation (2)):

Shannon-Weaver

$$
S=-\sum_{i} p_{i} \ln \left(p_{i}\right)
$$

where $\ln$ the natural logarithm and $p_{i}$ the proportion of system comprises category $i[70,75]$.

In both cases: The higher the value of the Shannon index is, the more even the balance is. According to [70] "all else being equal, the more even is the balance, the greater the diversity".

Social: In the social system balance relates to the question of how many actors are active in each type of social arena compared to the overall number of actors in the regional energy governance system. Role for resilience: From a resilience perspective, a high balance is related to a more even distribution of the viewpoints within the regional governance structure and provides stability to the system. This might, however, lead to decreasing efficiency as suggested by [51]. An uneven distribution of viewpoints might lead to a domination by one party and potentially foster a transition, but also lead to a neglect of significant aspects for the stabilization of each transition step.

Technical: In the technical system balance refers to the share of each technology group in the overall energy production [70]. Role for resilience: From a resilience perspective, a high balance implies a more even distribution of technologies might provide a lower stability (different load types must be handled etc.), and potentially a higher degree of flexibility and adaptability, depending, however, on the type of technology. A low balance means that energy generation is driven by mostly a specific technology group. This potentially leads to a higher stability of the system but at the same time to a lower degree of flexibility and potential for adaptability.

\subsubsection{Disparity}

Disparity relates to "the manner and the degree in which the elements may be distinguished" [64] (p. 709). We suggest to calculate a multi-attributive disparity [70,71,76] (Table 1, Equation (3)). Thereby disparity $\left(D_{i}\right)$ is a function of the different attributes characterizing either the arenas or the technology groups $[60,70]$ :

$$
D_{i}=f\left(d_{i j}\right)
$$

$f\left(d_{i j}\right)$ : function of distance in disparity space between categories $i$ and $j$.

With the analysis of the multi-attributive disparity we can account for different attributes of the social and technical systems. According to [64] (p. 709) "all else being equal, the more disparate are the presented elements, the greater the diversity".

Social: In the social system disparity relates to the question how different from each other the arenas are. Possible attributes for the disparity analysis are (i) time horizon of different actors (short-term for entrepreneurs vs. medium-term for politicians) [31]; (ii) their modes of action (communication, coordination); (iii) their structure, and functionality (legislation for politicians, investments for entrepreneurs) [20]; (iv) and their spatial reference (regional for politicians, cross-regional for entrepreneurs, local for private households) [31]. Role for resilience: From a resilience perspective the higher the disparity among the arenas, the higher is the adaptive capacity of the social system because different and diverse types of knowledge and viewpoints can be integrated into the regional energy discourse. A high disparity, thus, contributes to avoiding "short-sightedness" within the social system and creates new options and strategy spaces. Low disparity implies that the knowledge base and 
viewpoints of the arenas involved are similar. This lowers the transaction costs, makes the system more efficient and potentially stabilizes it, however, potentially reducing its adaptive capacity.

Technical: For the technical system attributes for analyzing the disparity of the different energy production technologies can be: (i) Type and availability or scarcity of energy carrier; (ii) $\mathrm{CO}_{2}$ emissions; (iii) Dependency on weather (sun or wind); (iv) Production costs; (iv) Surface consumption per kWh; and (v) efficiency of each technology group [69,77-82]. Role for resilience: From a resilience perspective disparity is the system's structural basis to "choose" between qualitatively diverse alternatives. High disparity provides a broad portfolio of options for a system to develop and is a crucial factor in terms of preparedness to especially unforeseen shocks. Low disparity means that the technology "portfolio" to choose from is rather limited, having, e.g., similar dependencies on environmental conditions or similar environmental impacts. Low disparity also implies a low flexibility and adaptive capacity. It can also imply a high redundancy, making the system more stable.

\subsection{Connectivity}

We build upon basic concepts from network analysis in order to operationalize connectivity in the technological and social sphere. Based on the social network analysis literature $[83,84]$, as well as the application of network metrics to energy systems [57], we identify three main aspects of connectivity, namely path length, centrality and modularity.

\subsubsection{Average Path Length}

The average path length describes how many intermediate steps must be taken to establish a connection between any two components of a system (Table 2). A short average path-length allows a system to be more easily steered, and for information to circulate faster [84].

Table 2. Suggested measures for operationalizing connectivity in socio-technical energy systems.

\begin{tabular}{|c|c|c|c|}
\hline $\begin{array}{l}\text { Connectivity } \\
\text { Indicator }\end{array}$ & Definition & Social System & Technical System \\
\hline $\begin{array}{l}\text { Average Path } \\
\text { Length }\end{array}$ & $\begin{array}{l}\text { Average path length } \\
l_{G}=i>j l(i, j) n(n)(n-1)^{2}[85] \\
\text { with average path length in the } \\
\text { network being the arithmetical } \\
\text { mean of all the distances. } \\
l_{G}=\frac{1}{n(n-1)} \sum_{i \neq j} d_{i j}[85]\end{array}$ & $\begin{array}{l}\text { Number of steps it takes to } \\
\text { reach other actors from other } \\
\text { arenas along the shortest path. } \\
\text { Role for resilience: } \\
\text { A shorter path length facilitates } \\
\text { the sharing of knowledge } \\
\text { and experience. }\end{array}$ & $\begin{array}{l}\text { Length of the transmission } \\
\text { lines between production and } \\
\text { consumption sites. } \\
\text { Role for resilience: } \\
\text { A shorter path length speeds } \\
\text { up the propagation of harmful } \\
\text { supply perturbations. }\end{array}$ \\
\hline $\begin{array}{l}\text { Degree } \\
\text { Centrality }\end{array}$ & $\begin{array}{l}\text { Degree Centrality } \\
C_{D}\left(n_{i}\right)=d\left(n_{i}\right)=\sum x_{i j}=\sum x_{j i}[84] \\
\text { The degree centrality of a node is } \\
\text { calculated by summing up the } \\
\text { connections that a node has to other } \\
\text { components in the network. } \\
\text { One can distinguish between in- } \\
\text { and out-degree centrality. } \\
\text { The Average Degree, which is an } \\
\text { indicator of the overall density of } \\
\text { the network, can be defined as: } \\
\bar{d}=\frac{\sum_{i=1}^{g} d\left(n_{i}\right)}{g} \text { [84] }\end{array}$ & $\begin{array}{l}\text { Number of connections of actors } \\
\text { within one arena to actors in } \\
\text { other arenas in comparison to } \\
\text { overall possible number of } \\
\text { connections. } \\
\text { Role for resilience: } \\
\text { A higher centrality reflects } \\
\text { a higher coordination power. }\end{array}$ & $\begin{array}{l}\text { Number of connections to } \\
\text { other producers or/and } \\
\text { consumers in the } \\
\text { distribution network. } \\
\text { Role for resilience: } \\
\text { High degree centrality, } \\
\text { Nodes represent } \\
\text { Intervention points. }\end{array}$ \\
\hline Modularity & $\begin{array}{l}\text { Modularity Index } \\
Q=\sum_{i}\left(e_{i i}-a_{i}\right)^{2} \text { [86] } \\
\text { where } e_{i i} \text { is the fraction of edges in } \\
\text { the network between any two nodes } \\
\text { in the module } i \text {, and } a_{i} \text { the total } \\
\text { fraction of links originating from it } \\
\text { and connecting nodes belonging to } \\
\text { different ones. }\end{array}$ & $\begin{array}{l}\text { Measure of the tendency of } \\
\text { actors from different arenas to } \\
\text { form subgroups which are } \\
\text { detached from the rest of } \\
\text { the network. } \\
\text { Role for resilience: } \\
\text { Higher modularity increases the } \\
\text { creation of new ideas within } \\
\text { partially secluded subgroups. }\end{array}$ & $\begin{array}{l}\text { Measure of autonomy of } \\
\text { certain parts of the } \\
\text { distribution network } \\
\text { Role for resilience: } \\
\text { Higher modularity allows } \\
\text { an autonomous functioning of } \\
\text { parts of the system (islanding) }\end{array}$ \\
\hline
\end{tabular}


Social: Applied to the social part of the system, the average path length can be interpreted as the relative social distance between actors from different social arenas. It can be measured by looking at whether actors are in direct contact with one another, and if not, how many mediating steps lay between them $[87,88]$. A shorter average path length between actors from different arenas allows for a faster propagation of information between the social arenas. This is important to have an exchange on different views of how to further develop the energy system with respect to transition goals, as well as to coordinate network activities in an efficient way $[85,89]$. Role for resilience: direct communication channels between actors from different arenas related to low average path length strengthens resilience by allowing for effective short-term collaborative action in the face of imminent shocks. Furthermore, efficient sharing of knowledge and experience across different arenas due to direct links between actors also allows for a higher adaptive capacity of the system in the longer run $[83,88]$.

Technical: Average path-length in the technical system can be understood as the average length of the transmission lines between different nodes (production \& consumer). While longer path lengths imply a higher loss of energy given a stable loss per km of wire, the propagation "speed" of supply perturbation will most likely be lower in systems with higher path lengths, i.e., with more potential intervention points (nodes) for a given grid size. Role for resilience: Higher-path length (more nodes between different parts of the system) results in a slowing-down of the propagation of harmful supply perturbations. Ash and Newth [90] suggested that longer path lengths can be a stabilizing factor increasing resilience in technical systems that are prone to cascading effects, such as energy distribution networks.

\subsubsection{Degree Centrality}

Degree centrality describes the relative position of a network component (actors, electricity production sites etc.) with respect to the other components of the system [91,92]. It is calculated as the number of direct links that exist between a network component and its network environment [83,93]. When looking at the system as a whole, average degree describes the overall centralization of the network, in other words the concentration of network ties linked to individual actors or system components, as the sum of the individual degree centrality measures in relation to the overall number of possible ties. Components with an over-average centrality in a system can be described as hubs, which are central for the functioning of a networked system due to their role as connecting entities (brokers), building bridges between otherwise unconnected actors and/or technical components of the system [90].

Social: Degree centrality measures can be applied to measure the importance of actors within the social arenas with respect to their capacity to be in direct contact with other actors both within as well as across arena boundaries. The higher degree centrality is, the higher the coordination power of actors within the system, e.g., with regard to planning and implementing changes to the production and distribution capacities of the regional energy system. High degree centrality supports actors in making their concerns heard. Due to their central position in the network, central actors can actively steer governance processes, and take influence on others. On the downside, if central actors are exposed to too many obligations, they may also be constrained in taking specific, especially unpopular, action [94,95]. Role for resilience: in the face of system-wide shocks, the initiation and coordination of collaborative action by central actors, who can directly communicate with many other actors across the various arenas allows for a swift implementation of specific adaptation measures. Central actors can be important to steer collective action in social systems, by coordinating activities across arena boundaries. Central actors can also have the power to slow down or even prevent a system to adapt to changing circumstances if they follow certain vested interests [88]. Central actors can also act as knowledge brokers across arena boundaries, giving them high power in what information they distribute, for example concerning financial or technical issues [96]. 
Technical: Within the technical system, degree centrality measures can be applied to estimate the role technology groups (e.g., solar, wind, etc.) have with respect to both the overall output they generate, as well as to the number of pro-/consumers they are linked to. If centrality is high, the production or distribution sites of the individual technology groups can be seen as local hubs of the system, which are critical for the system's stability and should be protected, especially in scale-free networks [90]. As centrality partially correlates with modularity, high-centrality nodes bridging between (production-) modules have an above average importance for the stability of the system as a whole $[84,85,97,98]$. Role for resilience: central nodes represent intervention points to allow for a swift (re-)stabilization of the system's functioning in presence of external or internal shocks, but high overall degree centrality can also have a destabilizing effect on (energy) network if these hubs are removed or destabilized. Ash and Newth [90] proposed that interconnection of hubs (nodes with high centrality measures) allow for a quick distribution and hence absorption of disturbances (p. 681), thus propagating inter-hub connectivity. Other authors have come up with contrary views, stressing the danger of (involuntary) hub-removals [99].

\subsubsection{Modularity}

Network modules describe parts of the network that share above-average interaction intensity (when compared to the system as a whole) and that are partially detached from other parts of the network $[100,101]$. Modularity measures can either be applied to predetermined entities (such as social arenas) and be utilized to distinguish between in-group versus out-group connection, or can be applied to investigate overall network structures [102].

Social: Modularity measures can be applied to measure the interaction intensity within social arenas versus the interaction intensity between social arenas (see [87] for an application in the tourism sector). If the modularity index is high, this means that many subgroups exist, which may be detrimental to overall cooperation in the system. Low modularity measures indicate a homogenous distribution of connections within the network, with actors from various arenas sharing similar numbers of connections and a high potential for exchange of information across arena boundaries. Role for resilience: High modularity can lead to an intense sharing of new ideas within partially secluded subgroups, resulting in higher (local) innovation, and therefore higher overall adaptive capacity of the system $[94,95]$. At the same time, high modularity can impede the flow of information between actors that are not part of the same subgroup. If subgroups form across arena boundaries, the variety of information shared is higher when compared to subgroups that are formed of actors from the same arena. This is important when it comes to support regional (social) innovation processes [96], which can lead to higher long-term resilience of the system by supporting both resistance and adaptive capacity.

Technical: In the technical system, modularity measures describe the presence of autonomous production or distribution modules within the overall network, which can sustain energy distribution independently over a certain period of time. An autonomous functioning of certain parts of the system allows a blocking-off of harmful effects by islanding parts of the network [103]. Role for resilience: [104] suggest that the resilience of a system increases, if the overall modularity or/and the clustering of a system increases. They relate this to concepts of edge resilience and node resilience (see [98] p. 116). Shocks spread less quickly in modularized networks, and can be "blocked" at the entrance node to the module. Linked to this, Roege et al. [57] postulate that—given a certain modular structure-system components (modules) can function autonomously, if the essential functional aspects are covered within the module itself. This is important in order to be able to detach parts of the network in the case of (localized) perturbations, allowing for an overall stabilization of the functioning of unaffected parts of the network, and thereby increasing the resilience of the network as a whole. 


\section{Discussion}

In the previous sections, we conceptualized resilience for energy systems as STS in transition, taking into account both the social and the technical aspects. We operationalized the resilience of socio-technical systems in transition based on the key attributes diversity and connectivity and derived a set of indicators related to diversity and to connectivity patterns of the system. In the following we engage in a discussion on: (1) Possible effects of different degrees of diversity and connectivity on the resilience of transitions; (2) Implications of measuring the resilience of transitions for energy systems; and (3) Future research needs.

\subsection{Effects of Different Degrees of Diversity and Connectivity on the Resilience of Transitions}

To understand how the selected indicators, relate to the resilience of a transition, we have to combine the levels of each indicator presented above first at the level of attribute (i.e., diversity and connectivity), second at the level of the system (social and technical), and third at the integrated level, i.e., social-technical system. It must be considered that there is no linear relationship between the indicators (and the levels) and the resilience of the transition. This means, as presented above, the resilience of the system increases if there is a higher modularity, but obviously if the system is too modular the resilience might decrease again, suggesting rather an u-curve than a linear relationship [51]. Thus, in the following we illustrate theoretically for four cases how different extreme values of diversity and connectivity might mirror different states of the resilience of a transition. The empirical analysis of two energy regions using these indicators follows in part two of this work: An indicator-based approach for analyzing the resilience of transitions for energy regions. Part II: Empirical applications.

Regarding diversity the necessity of looking at the three indicators in an integrative way is best stated by [100] (p. 1627) "... the most serious difficulty with conventional variety-balance indices concerns the neglect of the crucial property of disparity ... . This can yield manifest perverse results ... ". We consider the same to be true if we aggregate the three indicators. Thereby, a key question is how the weight of the three different indicators is defined. Furthermore, as shown by [105] the same value of the aggregate indicator can be obtained with different values of the three indicators, however, having a completely different outcome. In addition, for example, in the beginning of the transition, there might be a high variety of arenas, whereas their balance comes only at a later stage.

The same is true for connectivity. While connectivity measures are inherently interrelated with one another, the distinction between the three indicators helps to understand the underlying drivers and barriers of cooperation and collaboration in the social sphere, which helps to build stability and adaptive capacity along the transient pathway by means of steering current and future development, and enabling innovation. In the technical sphere, the three connectivity measures allow to assess the structural resilience of the system with regard to both external shocks, and internal disruptions. This helps decision-makers to plan further adjustments in the energy infrastructure to drive the transition towards higher sustainability.

We consider that what is true for diversity and connectivity is also true for the combination of these two attributes. That is, the resilience of a transition cannot be studied by only considering diversity or connectivity or by only analyzing the technical or social systems independent from each other. In the following we illustrate in the form of fictive scenarios four possible constellations of diversity and connectivity components and discuss their implications for transitions.

\section{Case A (Diversity high, connectivity high):}

The regional energy governance system is composed of a high variety of types of actors, which are well distributed across the social arenas and which are very different from one another (e.g., politics, artists, businesses). The actors are organized in distinct modules, which have a well-defined and well-elaborated communication structure composed of direct communication paths, with low average path lengths. There is a clearly defined central actor ensuring that the system is able to react to potential crisis situations while still maintaining its governance stability. In the technical system, there is a diverse 
amount of different technology groups, which are different from each other and which occur in the same share. This provides for a large and balanced technology portfolio. The different technologies are so well connected to each other that despite the large portfolio, the efficiency of the energy system is not negatively touched upon. The central organization (e.g., energy region manager) also supports an efficient combination of the different energy technologies. In such a constellation, it is very likely that an energy transition might be successful and fully supported by the social system and well embedded into the current technical energy system. This would be an ideal-typical case of a resilient transition.

\section{Case B (Diversity low, connectivity low):}

The regional energy governance system is composed only of 1 or 2 very similar arenas (e.g., city and community representatives) who have a segmented view of the social system within the energy transition. The measures taken are shortsighted and do not consider all the actors involved, thus, hampering the social acceptability of the transitions process itself. The low degree of centrality (e.g., no central managing actor) leads to a lack of central steering power by individual actors in the social system which allows for uncontrolled growth of individual technical initiatives. In the technical system, the technology portfolio consists of a few technology types, e.g., solar and nuclear, which are not well balanced themselves. The high amount of, e.g., solar energy producers, who are not well integrated into the grid, resulting in long average transmission paths, makes the system difficult to be steered. This constellation is likely to cause severe technical, economic, and governance inefficiencies and the energy transition is likely to fail. One empirical case that can partly be related to this constellation is the case of the ökoEnergieland in Austria [19]. The transition process towards withdrawal from fossil fuels was mainly initiated by two visionary leaders, the town's engineer and the mayor of the town of Güssing. One key innovation in the region was the development of the first combined heat-power plant, installed in the town of Güssing. This plant provided a large share of the renewable energy used in the region. In the further development of the transition one could observe increases in the diversity of actors and technologies, however, a dominance of the two founders and the combined heat-power technology prevailed and even though they were establishments of several businesses in the region the connectivity with other relevant players in the region was rather low mimicked in the populations lack of awareness and interest concerning energy-related issues [33]. However, a high share of renewables in the energy portfolio was reached (amounting up to 52\% in 2010 [19]). This low diversity and connectivity finally, among other factors, led to a bankruptcy of the region in 2011 and 2016 [106-108].

\section{Case C (Diversity high, connectivity low):}

The regional energy governance system is composed of a high variety of types of actors, which are well distributed across the social arenas and are different from one another (e.g., politics, artists, businesses). However, the actors are not well organized and have not established a clear communication structure. Thus, communication takes a long time, is inefficient and often does not reach the correct addressee. There are several central actors causing high transaction costs and low reactivity within the system. In the technical system, there is a diverse amount of technology groups with a very similar overall share. This provides a large and balanced technology portfolio. As the different technologies are not well connected to each other, the transmission pathways are long, causing high inefficiencies within the energy system. As there is no explicit central organization, i.e., there are no central actors with steering capacity coordinating the development of and coordination between the large amount of technologies prevalent in the region. In such a constellation, there are two forces that could affect the transition. On the one hand diversity measures indicate an optimal starting point for further developments toward the transition goal. On the other hand, as the system components are not well connected and high inefficiencies prevail, it is not clear whether the energy transition would fail or would reach a stabilization point, if connectivity is further enhanced. Case $C$, thus, could indicate an intermediate stage within the transition of the regional energy system. A case that has some aspects 
of this constellation, is the energy transformation in the energy region Weiz-Gleisdorf (see also Part II: Empirical applications). This case shows high diversity in the social and technical systems, a high connectivity in the social system, but a rather low connectivity in the technical system. The share of renewable energies in the regions was around $26 \%$ in 2010 [33].

\section{Case D (Diversity low, connectivity high):}

The regional energy governance system is composed only of 1 or 2 very similar arenas (e.g., city and community representatives), who have a segmented view of the social system within the energy transition. The measures taken are shortsighted and do not consider all the actors involved, thus hindering the social acceptability of the transitions process itself. There is nevertheless a high degree of centrality and the actors are organized in modules. This and very efficient communication ways ensure that the system can react, even though only partly, to external demands. In the technical system the portfolio consists of a few technology types, e.g., solar and nuclear, which are not well balanced themselves. The high amount of, e.g., solar energy producers or large wind energy producers is well integrated into the grid, resulting in short average path lengths, and there is well established modular system in place, so that the energy technologies which are present are easy to handle and to steer in case of external perturbations. This constellation is likely to lead to a partially stable transition as on the one hand the available technologies are well managed but, on the other hand, relevant technologies might not be considered and thus not integrated into the transition. The low integration of the different arenas leads to low acceptability and potentially low inclusion of relevant actors hindering a complete transition. An example for this type of transition could be the transitions in the northern part of Germany, where the regions rely mostly on wind energy as the sources of renewable energy. These four examples showed that when studying the resilience of the transition of an energy system it is essential to include both the aspects of diversity and connectivity, as well as the social and technical systems. If we would neglect one or the other we would run into the problem of taking wrong decisions and making wrong policy recommendations.

\subsection{Implication for Measuring Resilience along the Transition Path}

When reflecting on the role of diversity and connectivity for resilience, following the logic of the adaptive cycle [56] the overall level of diversity is likely to decrease over the course of a transition, while the overall level of connectivity might increase. Our case A above shows for the energy system that even a high diversity can lead to a high resilience if the connectivity of the system is set-up in an optimal way.

In the technical system, the balance and disparity are likely to decrease along the transition path, due to economies of scale, while variety is likely to stabilize at a certain point (number of mature technologies). With regard to connectivity, the centrality will likely increase both in the social and technical systems, because a smaller number of actors and production sites will provide the same level of service, while the (qualitative) differentiation between the units increases over time. The average path length is likely to stabilize at a level that allows efficient processes, while allowing for a certain structural flexibility.

\subsection{Future Research}

Further research should focus on two main aspects. First, a further differentiation with the concepts of diversity and connectivity is needed, regarding the question, whether and how an integrated set of indicators should be built and how their different levels can be interpreted with respect to the resilience of the transition process. Second, the indicators have to be tested empirically to ensure their applicability, interpretability and usability for policy development. We propose an empirical application of the indicators to an Austrian case study region in An Indicator-Based Approach for Analyzing the Resilience of Transitions for Energy Regions. Part II: Empirical Application (also part of the present Special Issue). 


\section{Conclusions}

In this paper, we conceptualize and operationalize the resilience of socio-technical energy systems in transition. We take up a resilience understanding from social-ecological systems (SES) research and apply it to regional energy systems. We derive a set of six indicators related to diversity and connectivity, which characterize the resilience of a regional energy system. Diversity can be measured by variety, balance and disparity of the system, whereas connectivity can be measured by average path length, degree centrality and modularity. These indicators provide metrics for analyzing the resilience of energy transitions across regions. They allow for an empirical investigation into the different structural aspects of energy systems in transition, and their evolution over time.

For analyzing the resilience of the transition at a certain stage of the transitions it is important to look at the six indicators simultaneously. The four theoretical examples presented show that only when studying the six indicators concomitantly we can achieve a meaningful interpretation of the results. The precise way of how the diversity and connectivity measures relate to each other in practice is subject to further empirical analysis.

Regarding the role of diversity and connectivity along the transition path, our theoretical analyses suggest that diversity is likely to decrease along the transition path, while connectivity is likely to increase. Thereby the development of each of the indicators relating to diversity and connectivity might vary from each other.

Further research will have to determine the explanatory power of our indicators for the analysis of resilience in energy transitions in general, and provide insights on how regional characteristics and political regulations, affect the real-world values of the diversity and connectivity measures. This will allow us to derive contextual policy-recommendations for a resilient management of regional energy transitions in the future.

Acknowledgments: The authors thank two anonymous reviewers, Thorsten Schilling and Thomas Bauwens for comments on the conceptualization and earlier versions of this paper. We thank Swiss Mobiliar for co-funding this research.

Author Contributions: All authors contributed equally to the design and writing process of this publication.

Conflicts of Interest: The authors declare no conflict of interest.

\section{References}

1. Leipprand, A.; Flachsland, C.; Pahle, M. Energy transition on the rise: Discourses on energy future in the German parliament. Innov. Eur. J. Soc. Sci. Res. 2016. [CrossRef]

2. Öffentlichkeitsarbeit B für W und E Referat. Eine Zielarchitektur für die Energiewende: Von Politischen Zielen bis zu Einzelmaßnahmen. Available online: http://www.bmwi.de/DE/Themen/Energie/ Energiewende/zielarchitektur.html (accessed on 7 October 2016).

3. Österreichs E-Wirtschaft. Oesterreichs Energie-Investitionen der E-Wirtschaft. Available online: http://oesterreichsenergie.at/daten-fakten/statistik/investitionen-der-e-wirtschaft.html (accessed on 7 October 2016).

4. Deutsche Energie-Agentur GmbH (dena). Stromverteilnetze Müssen für die Energiewende Deutlich Ausgebaut Werden. Available online: http://www.dena.de/presse-medien/pressemitteilungen/stromverteilnetzemuessen-fuer-die-energiewende-deutlich-ausgebaut-werden.html (accessed on 7 October 2016).

5. Deutsche Energie-Agentur $\mathrm{GmbH}$ (dena). Ausbau-und Innovationsbedarf der Stromverteilnetze in Deutschland bis 2030. Available online: http://www.dena.de/fileadmin/user_upload/Projekte/ Energiesysteme/Dokumente/denaVNS_Abschlussbericht.pdf (accessed on 7 October 2016).

6. Bundesamt für Energie BFE. Energiestrategie 2050. Available online: http://www.bfe.admin.ch/ energiestrategie2050/index.html?lang=de (accessed on 7 October 2016).

7. Bundesministerium für Wirtschaft, Familie und Jugend, Bundesministerium für Land-und Forstwirtschaft, Umwelt und Wasserwirtschaft. Eckpunkte Energiestrategie; Bundesministerium für Wirtschaft, Familie und Jugend, Bundesministerium für Land-und Forstwirtschaft, Umwelt und Wasserwirtschaft: Wien, Austria, 2010. 
8. Presse-und Informationsamt der Bundesregierung. Energiewende im Überblick. Available online: https://www.bundesregierung.de/Content/DE/StatischeSeiten/Breg/Energiekonzept/0-Buehne/ma\% C3\%9Fnahmen-im-ueberblick.html;jsessionid=2B7A2CB0894799978EF6BBE19A93CC8B.s4t2 (accessed on 7 October 2016).

9. Eidgenössisches Departement für Umwelt, Verkehr, Energie und Kommunikation UVEK. Energiestrategie 2050. Available online: https://www.uvek.admin.ch/uvek/de/home/energie/energiestrategie-2050.html (accessed on 7 October 2016).

10. Bundesministerium für Wirtschaft und Energie BMWi. Investitionen in Erneuerbare Energien 2014 gestiegen. Available online: https://www.bmwi-energiewende.de/EWD/Redaktion/Newsletter/2015/6/Meldung/ infografik-investitionen-in-erneuerbare-gestiegen.html (accessed on 7 October 2016).

11. Rotmans, J.; Kemp, R.; Van Asselt, M. More evolution than revolution: Transition management in public policy. Foresight 2001, 3, 15-31. [CrossRef]

12. Rotmans, J.; Fischer-Kowalski, M. Conceptualizing, observing and influencing socio-ecological transitions. Ecol. Soc. J. Integr. Sci. Resil. Sustain. 2009, 14, 1-18.

13. Martens, P.; Rotmans, J. Transitions in a globalising world. Futures 2005, 37, 1133-1144. [CrossRef]

14. Grin, J.; Rotmans, J.; Schot, J. Transitions to Sustainable Development: New Directions in the Study of Long Term Transformative Change; Routledge: Florence, KY, USA, 2010.

15. Hodbod, J.; Adger, W.N. Integrating social-ecological dynamics and resilience into energy systems research. Energy Res. Soc. Sci. 2014, 1, 226-231. [CrossRef]

16. Johannsson, T.; Patwardhan, A.; Nakiecenovic, N.; Gomez-Echeverri, E. Global Energy Assessnent: Toward a Sustainable Future; Cambridge University Press: Cambridge, UK, 2012.

17. Breidenich, C.; Magraw, D.; Rowley, A.; Rubin, J.W. The Kyoto protocol to the United Nations framework convention on climate change. Am. J. Int. Law 1998, 92, 315-331. [CrossRef]

18. Eurostat. Nomenclature of Territorial Units for Statistics NUTS 2013/EU-28 Regions in the European Union; Eurostat: Luxembourg, 2015.

19. Hecher, M.; Vilsmaier, U.; Akhavan, R.; Binder, C.R. An integrative analysis of energy transitions in energy regions: A case study of ökoEnergieland in Austria. Ecol. Econ. 2016, 121, 40-53. [CrossRef]

20. Späth, P.; Koblmüller, M.; Kubeczko, K.; Faber, F.; Bärnthaler, J.; Bergmann, H. Energieregionen: Wirksame Leitbildprozesse und Netzwerke zur Regionalen Gestaltung Sozio-Technischen Wandels; Vienna BMVIT Berichte aus Energ-Umweltforsch: Vienna, Austria, 2007.

21. Trutnevyte, E.; Stauffacher, M.; Scholz, R.W. Linking stakeholder visions with resource allocation scenarios and multi-criteria assessment. Eur. J. Oper. Res. 2012, 219, 762-772. [CrossRef]

22. Trutnevyte, E. The allure of energy visions: Are some visions better than others? Energy Strategy Rev. 2014, 2, 211-219. [CrossRef]

23. Binder, C.R.; Hecher, M.; Vilsmaier, U. Visionen, Institutionen und Infrastrukturen als Elemente der Energietransformation; Campus Verlag: Frankfurt, Germany, 2014; pp. 267-286.

24. Gill, B.; Kropp, C.; Böschen, S.; Vogel, K. Klima von Unten: Regionale Governance und Gesellschaftlicher Wandel; Campus Verlag: Frankfurt, Germany, 2014.

25. Kern, F.; Smith, A. Restructuring energy systems for sustainability? Energy transition policy in the Netherlands. Energy Policy 2008, 36, 4093-4103. [CrossRef]

26. Verbong, G.; Geels, F. The ongoing energy transition: Lessons from a socio-technical, multi-level analysis of the Dutch electricity system (1960-2004). Energy Policy 2007, 35, 1025-1037. [CrossRef]

27. Foxon, T.J. A coevolutionary framework for analysing a transition to a sustainable low carbon economy. Ecol. Econ. 2011, 70, 2258-2267. [CrossRef]

28. Binder, C.R.; Knoeri, C.; Hecher, M. Modeling transition paths towards decentralized regional energy autonomy: The role of legislation, technology adoption, and resource availability. Raumforsch. Raumordn. 2016, 74, 273-284. [CrossRef]

29. Coutard, O.; Rutherford, J. Energy transition and city-region planning: Understanding the spatial politics of systemic change. Technol. Anal. Strateg. Manag. 2010, 22, 711-727. [CrossRef]

30. Ruth, M.; Özgün, O.; Wachsmuth, J.; Gößling-Reisemann, S. Dynamics of energy transitions under changing socioeconomic, technological and climate conditions in Northwest Germany. Ecol. Econ. 2015, 111, $29-47$. [CrossRef] 
31. Binder, C.R.; Hofer, C.; Wiek, A.; Scholz, R.W. Transition towards improved regional wood flows by integrating material flux analysis and agent analysis: The case of Appenzell Ausserrhoden, Switzerland. Ecol. Econ. 2004, 49, 1-17. [CrossRef]

32. Späth, P.; Rohracher, H. "Energy regions": The transformative power of regional discourses on socio-technical futures. Res. Policy 2010, 39, 449-458. [CrossRef]

33. Binder, C.; Bedenik, K.; Chappin, E.; Dijkema, G.; Goetz, A.; Hecher, M. Transition Dynamics in Energy Regions: An Integrated Model for Sustainable Policies; Project Report to the Austrian Climate Fund; Karl-Franzens-Universität Graz: Graz, Austria, 2014.

34. Gailing, L.; Röhring, A. Was ist dezentral an der Energiewende? Infrastrukturen erneuerbarer Energien als Herausforderungen und Chancen für ländliche Räume. Raumforsch. Raumordn. 2015, 73, 31-43. [CrossRef]

35. O'Brien, G.; Hope, A. Localism and energy: Negotiating approaches to embedding resilience in energy systems. Energy Policy 2010, 38, 7550-7558. [CrossRef]

36. Schilling, T. Resilienz und Transitionen in Komplexen Adaptiven Systemen. Eine Theoretische Verknüpfung Zweier Systemdynamischer Perspektiven. For Change Working Paper 8. Available online: https://resilienz. hypotheses.org/554 (accessed on 7 October 2016).

37. Schilling, T.; Wyss, R.; Binder, C.R. Going beyond the threshold-Theoretical implications on a new way to look at societal transitions from a dynamic resilience perspective forthcoming. École Polytechnique Fédéral de Lausanne (EPFL), Lausanne, Switzerland. Unpublished work, 2016.

38. Mühlemeier, S.; Wyss, R.; Binder, C.R. Die Energiewende aus der Sicht ihrer Pioniere: Motivationen, Strategien und die Wahrnehmung entscheidender Umwelteinflüsse der regionalen Energiewende im bayerischen Allgäu. forthcoming. Ecol. Econ. 2016, submitted for publication.

39. Moss, T.; Becker, S.; Naumann, M. Whose energy transition is it, anyway? Organisation and ownership of the Energiewende in villages, cities and regions. Local Environ. 2015, 20, 1547-1563. [CrossRef]

40. Sovacool, B.K. The History and Politics of Energy Transitions: Comparing Contested Views and Finding Common Ground; WIDER Working Paper; United Nations University: Tokyo, Japan, 2016.

41. Strunz, S. The German energy transition as a regime shift. Ecol. Econ. 2014, 100, 150-158. [CrossRef]

42. Späth, P.; Rohracher, H. Local demonstrations for global transitions-Dynamics across governance levels fostering socio-technical regime change towards sustainability. Eur. Plan. Stud. 2012, 20, 461-479. [CrossRef]

43. Sensfuß, F.; Ragwitz, M. Weiterentwickeltes Fördersystem für die Vermarktung von erneuerbarer Stromerzeugung. In Proceedings of the 7th Internationale Energiewirtschaftstagung an der TU Wien, Wien, Austria, 16-18 February 2011.

44. Linkov, I.; Eisenberg, D.A.; Plourde, K.; Seager, T.P.; Allen, J.; Kott, A. Resilience metrics for cyber systems. Environ. Syst. Decis. 2013, 33, 471-476. [CrossRef]

45. Bruns, E.; Futterlieb, M.; Ohlhorst, D.; Wenzel, B. Netze als Rückgrat der Energiewende: Hemmnisse für die Integration Erneuerbarer Energien in Strom-, Gas-und Wärmenetze; Technische Universität: Berlin, Germany, 2012.

46. Schill, W.-P. Systemintegration erneuerbarer Energien: Die Rolle von Speichern für die Energiewende. Vierteljahrsh. Wirtsch. 2013, 82, 61-88. [CrossRef]

47. Olsson, P.; Galaz, V.; Boonstra, W.J. Sustainability transformations: A resilience perspective. Ecol. Soc. 2014, 19, 1-13. [CrossRef]

48. Walker, B.; Holling, C.S.; Carpenter, S.R.; Kinzig, A. Resilience, adaptability and transformability in social-ecological systems. Ecol. Soc. 2004, 9, 5. [CrossRef]

49. Folke, C. Resilience: The emergence of a perspective for social-ecological systems analyses. Glob. Environ. Chang. 2006, 16, 253-267. [CrossRef]

50. Fath, B.D.; Dean, C.A.; Katzmair, H. Navigating the adaptive cycle: An approach to managing the resilience of social systems. Ecol. Soc. 2015, 20, 24. [CrossRef]

51. Lietaer, B.; Ulanowicz, R.E.; Goerner, S.J.; McLaren, N. Is our monetary structure a systemic cause for financial instability? Evidence and remedies from nature. J. Future Stud. 2010, 14, 89-108.

52. Holling, C.S. Resilience and stability of ecological systems. Annu. Rev. Ecol. Syst. 1973, 4, 1-23. [CrossRef]

53. Holling, C.S. The Resilience of Terrestrial Ecosystems: Local Surprise and Global Change; Cambridge University Press: Cambridge, UK, 1986; pp. 292-317.

54. Folke, C.; Carpenter, S.R.; Walker, B.; Scheffer, M.; Chapin, T.; Rockstrom, J. Resilience thinking: Integrating resilience, adaptability and transformability. Ecol. Soc. 2010, 15, 20. 
55. Foxon, T.J.; Reed, M.S.; Stringer, L.C. Governing long-term social-ecological change: What can the adaptive management and transition management approaches learn from each other? Environ. Policy Gov. 2009, 19, 3-20. [CrossRef]

56. Gunderson, L.H. Panarchy: Understanding Transformations in Human and Natural Systems; Island Press: Washington, DC, USA, 2001.

57. Roege, P.E.; Collier, Z.A.; Mancillas, J.; McDonagh, J.A.; Linkov, I. Metrics for energy resilience. Energy Policy 2014, 72, 249-256. [CrossRef]

58. Rochas, C.; Kuzņecova, T.; Romagnoli, F. The concept of the system resilience within the infrastructure dimension: Application to a Latvian case. J. Clean. Prod. 2015, 88, 358-368. [CrossRef]

59. Smith, A.; Stirling, A. Social-Ecological Resilience and Socio-Technical Transitions: Critical Issues for Sustainability Governance; STEPS Centre: Brighton, UK, 2008.

60. Smith, A.; Stirling, A. The politics of social-ecological resilience and sustainable socio-technical transitions. Ecol. Soc. 2010, 15, 11. [CrossRef]

61. Ostrom, E. A diagnostic approach for going beyond panaceas. Proc. Natl. Acad. Sci. USA 2007, 104, 15181-15187. [CrossRef] [PubMed]

62. Ostrom, E. A general framework for analyzing sustainability of social-ecological systems. Science 2009, 325, 419-422. [CrossRef] [PubMed]

63. Vespignani, A. Modelling dynamical processes in complex socio-technical systems. Nat. Phys. 2012, 8, 32-39. [CrossRef]

64. Little, R. A socio-technical systems approach to understanding and enhancing the reliability of interdependent infrastructure systems. Int. J. Emerg. Manag. 2004, 2, 98-110. [CrossRef]

65. Gunderson, L. Resilience, flexibility and adaptive management-Antidotes for spurious certitude. Conserv. Ecol. 1999, 3, 7. [CrossRef]

66. Folke, C.; Carpenter, S.; Elmqvist, T.; Gunderson, L.; Holling, C.S.; Walker, B. Resilience and sustainable development: Building adaptive capacity in a world of transformations. AMBIO J. Hum. Environ. 2002, 31, 437-440. [CrossRef]

67. Ernstson, H.; Barthel, S.; Andersson, E.; Borgström, S.T. Scale-crossing brokers and network governance of urban ecosystem services: The case of Stockholm. Ecol. Soc. 2010, 15, 28.

68. Luthe, T.; Wyss, R. Introducing adaptive waves as a concept to inform mental models of resilience. Sustain. Sci. 2015, 10, 673-685. [CrossRef]

69. Kost, C.; Mayer, J.N.; Thomsen, J.; Hartmann, N.; Senkpiel, C.; Philipps, S. Stromgestehungskosten Erneuerbare Energien; Fraunhofer ISE: Freiburg im Breisgau, Germany, 2013.

70. Stirling, A. A general framework for analysing diversity in science, technology and society. J. R. Soc. Interface 2007, 4, 707-719. [CrossRef] [PubMed]

71. Stirling, A. On the economics and analysis of diversity. Sci. Policy Res. Unit SPRU 1998, 28, 1-156.

72. Sokal, R.; Sneath, P. Principles of Numerical Taxonomy; Freeman: San Francisco, CA, USA, 1970.

73. Grünwald, R.; Ragwitz, M.; Sensfuß, F.; Winkler, J. Regenerative Energieträger zur Sicherung der Grundlast in der Stromversorgung; Endbericht Zum Monit Arbeitsbericht; Büro für Technikfolgen-Abschätzung beim Deutschen Bundestag: Berlin, Germany, 2012.

74. Grimm, V. Einbindung von Speichern für erneuerbare Energien in die Kraftwerkseinsatzplanung-Einfluss auf die Strompreise der Spitzenlast. Ph.D. Thesis, Universitätsbibliothek Ruhr-Universität Bochum, Bochum, Germany, 2007.

75. Kharrazi, A.; Sato, M.; Yarime, M.; Nakayama, H.; Yu, Y.; Kraines, S. Examining the resilience of national energy systems: Measurements of diversity in production-based and consumption-based electricity in the globalization of trade networks. Energy Policy 2015, 87, 455-464. [CrossRef]

76. Awerbuch, S.; Stirling, A.; Jansen, J.C.; Beurskens, L.W.M. Full-Spectrum Portfolio and Diversity Analysis of Energy Technologies; Elsevier: Amsterdam, The Netherland, 2006; pp. 49-64.

77. Wissel, S.; Rath-Nagel, S.; Blesl, M.; Fahl, U.; Voss, A. Stromerzeugungskosten im Vergleich. Arbeitsbericht der Universität Stuttgart 2008. Available online: http://www.ier.uni-stuttgart.de/publikationen/ arbeitsberichte/downloads/Arbeitsbericht_04.pdf (accessed on 14 October 2016).

78. Burger, A.; Lünenbürger, B.; Osiek, D. Nachhaltige Stromversorgung der Zukunft: Kosten und Untzen Einer Transformation hin zu 100\% Emeuerbare Energien; Umweltbundesamt: Dessau-Roßlau, Germany, 2012. 
79. Peter, F.; Krampe, L.; Ziegenhagen, I. Entwicklung von Stromproduktionskosten-Die Rolle von FreiflächenSolarkraftwerken in der Energiewende; Belelectric Solarkraftwerke GmbH Berl: Kolitzheim, Germany, 2013.

80. Nestle, U.; Kunz, C. Studienvergleich: Stromgestehungskosten Verschiedener Erzeugungstechnologien; Forschungsradar Energiewende-Metaanalyse: Berlin, Germany, 2014.

81. Küchler, S.; Wronski, R. Was Strom Wirklich Kostet: Vergleich der Staatlichen Förderungen und Gesamtgesellschaftlichen Kosten von Konventionellen und Erneuerbaren Energien. Studie im Auftrag von Greenpeace Energy eG; BWE: Copenhagen, Denmark, 2015.

82. Reitberger, F. Die Begrenzte Ressource Fläche: Vortrag zu Flächenbetrachtungen im Rahmen der Energiewende; University of Vienna: Vienna, Austria, 2015.

83. Scott, J. Social Network Analysis; Services and Advocacy for GLBT Elders (SAGE): New York, NY, USA, 2012.

84. Wasserman, S.; Faust, K. Social Network Analysis: Methods and Applications; Cambridge University Press: Cambridge, UK, 1994; Volume 8.

85. Baggio, R.; Scott, N.; Cooper, C. Network science: A review focused on tourism. Ann. Tour. Res. 2010, 37, 802-827. [CrossRef]

86. Baggio, R.; Sainaghi, R. Mapping time series into networks as a tool to assess the complex dynamics of tourism systems. Tour. Manag. 2016, 54, 23-33. [CrossRef]

87. Luthe, T.; Wyss, R.; Schuckert, M. Network governance and regional resilience to climate change: Empirical evidence from mountain tourism communities in the Swiss Gotthard region. Reg. Environ. Chang. 2012, 12, 839-854. [CrossRef]

88. Wyss, R.; Luthe, T.; Abegg, B. Building resilience to climate change-The role of cooperation in alpine tourism networks. Local Environ. 2015, 20, 908-922. [CrossRef]

89. Sandström, A.; Carlsson, L. The performance of policy networks: The relation between network structure and network performance. Policy Stud. J. 2008, 36, 497-524. [CrossRef]

90. Ash, J.; Newth, D. Optimizing complex networks for resilience against cascading failure. Phys. Stat. Mech. Appl. 2007, 380, 673-683. [CrossRef]

91. Freeman, L.C. Centrality in social networks conceptual clarification. Soc. Netw. 1978, 1, 215-239. [CrossRef]

92. Weimann, G. On the importance of marginality: One more step into the two-step flow of communication. Am. Sociol. Rev. 1982, 47, 764-773. [CrossRef]

93. Marsden, P.V. Egocentric and sociocentric measures of network centrality. Soc. Netw. 2002, 24, 407-422. [CrossRef]

94. Bodin, Ö.; Crona, B.; Ernstson, H. Social networks in natural resource management: What is there to learn from a structural perspective. Ecol. Soc. 2006, 11, 395-402. [CrossRef]

95. Bodin, Ö.; Crona, B.I. The role of social networks in natural resource governance: What relational patterns make a difference? Glob. Environ. Chang. 2009, 19, 366-374. [CrossRef]

96. Luthe, T.; Wyss, R. Resilience to climate change in a cross-scale tourism governance context: A combined quantitative-qualitative network analysis. Ecol. Soc. 2016, 21. [CrossRef]

97. Nastos, J.; Gao, Y. Familial groups in social networks. Soc. Netw. 2013, 35, 439-450. [CrossRef]

98. Sharifi, A.; Yamagata, Y. On the suitability of assessment tools for guiding communities towards disaster resilience. Int. J. Disaster Risk Reduct. 2016, 18, 115-124. [CrossRef]

99. Albert, R.; Jeong, H.; Barabási, A.-L. Error and attack tolerance of complex networks. Nature 2000, 406, 378-382. [CrossRef] [PubMed]

100. Newman, M.E. Finding community structure in networks using the eigenvectors of matrices. Phys. Rev. E 2006, 74. [CrossRef] [PubMed]

101. Clauset, A.; Newman, M.E.; Moore, C. Finding community structure in very large networks. Phys. Rev. E 2004, 70. [CrossRef] [PubMed]

102. Baggio, R. Collaboration and cooperation in a tourism destination: A network science approach. Curr. Issues Tour. 2011, 14, 183-189. [CrossRef]

103. Trodden, P.A.; Bukhsh, W.A.; Grothey, A.; McKinnon, K.I.M. MILP formulation for controlled islanding of power networks. Int. J. Electr. Power Energy Syst. 2013, 45, 501-508. [CrossRef]

104. Rosenkrantz, D.J.; Goel, S.; Ravi, S.S.; Gangolly, J. Structure-Based Resilience Metrics for Service-Oriented Networks. In Dependable Computer-EDCC 5; Cin, M.D., Kaâniche, M., Pataricza, A., Eds.; Springer: Berlin/Heidelberg, Germany, 2005; pp. 345-362. 
105. Stirling, A. Multicriteria diversity analysis: A novel heuristic framework for appraising energy portfolios. Energy Policy 2010, 38, 1622-1634. [CrossRef]

106. Austria, R. Konkurs von Reinhard Koch Könnte Kettenreaktion Auslösen. Available online: http:/ / www.meinbezirk.at/guessing/wirtschaft/konkurs-von-reinhard-koch-koennte-kettenreaktionausloesen-d1688189.html (accessed on 21 December 2016).

107. Biomassekraftwerk Güssing Vorerst Gerettet. Available online: http://burgenland.orf.at/news/stories/ 2596350/ (accessed on 21 December 2016).

108. Güssing: Modellregion vor dem Aus. Available online: http://burgenland.orf.at/news/stories/2797785/ (accessed on 21 December 2016).

(C) 2017 by the authors; licensee MDPI, Basel, Switzerland. This article is an open access article distributed under the terms and conditions of the Creative Commons Attribution (CC-BY) license (http:/ / creativecommons.org/licenses/by/4.0/). 